\title{
Photosynthesis-irradiance responses in the Ross Sea, Antarctica: a meta-analysis
}

\author{
W. O. Smith Jr. and K. Donaldson \\ Virginia Institute of Marine Science, College of William \& Mary, Gloucester Pt., VA 23062, USA \\ Correspondence to: W. O. Smith Jr. (wos@vims.edu)
}

Received: 12 November 2014 - Published in Biogeosciences Discuss.: 19 December 2014

Revised: 21 April 2015 - Accepted: 5 May 2015 - Published: 10 June 2015

\begin{abstract}
A meta-analysis of photosynthesis-irradiance measurements was completed using data from the Ross Sea, Antarctica, using a total of 417 independent measurements. $P_{\mathrm{m}}^{\mathrm{B}}$, the maximum, chlorophyll-specific, irradiancesaturated rate of photosynthesis, averaged $1.1 \pm 0.06 \mu \mathrm{g} \mathrm{C}$ $(\mu \mathrm{g} \mathrm{Chl})^{-1} \mathrm{~h}^{-1}$. Light-limited, chlorophyll-specific photosynthetic rates $\left(\alpha^{\mathrm{B}}\right)$ averaged $0.030 \pm 0.023 \mu \mathrm{g} \mathrm{C}$ $(\mu \mathrm{g} \mathrm{Chl})^{-1} \mathrm{~h}^{-1} \quad\left(\mu \mathrm{mol} \text { quanta } \mathrm{m}^{-2} \mathrm{~s}^{-1}\right)^{-1}$. Significant variations in $P_{\mathrm{m}}^{\mathrm{B}}$ and $\alpha^{\mathrm{B}}$ were found as a function of season, with spring maximum photosynthetic rates being $60 \%$ greater than those in summer. Similarly, $\alpha$ values were $48 \%$ greater in spring. There was no detectable effect of sampling location on the photosynthetic parameters, and temperature and macronutrient $\left(\mathrm{NO}_{3}\right)$ concentrations also did not have an influence. However, irradiance and carbon dioxide concentrations, when altered under controlled conditions, exerted significant influences on photosynthetic parameters. Specifically, reduced irradiance resulted in significantly decreased $P_{\mathrm{m}}^{\mathrm{B}}$ and increased $\alpha^{\mathrm{B}}$ values, and increased $\mathrm{CO}_{2}$ concentrations resulted in significantly increased $P_{\mathrm{m}}^{\mathrm{B}}$ and $\alpha^{\mathrm{B}}$ values. Comparison of photosynthetic parameters derived at stations where iron concentrations were above and below $0.1 \mathrm{nM}$ indicated that reduced iron levels were associated with significantly increased $P_{\mathrm{m}}^{\mathrm{B}}$ values, confirming the importance of iron within the photosynthetic process. No significant difference was detected between stations dominated by diatoms and those dominated by the haptophyte Phaeocystis antarctica. The meta-analysis confirms the photosynthetic rates predicted from global analyses that are based solely on temperature and irradiance availability, but suggests that, for more accurate predictions of productivity in polar systems, a more detailed model that
\end{abstract}

includes temporal effects of photosynthetic parameters will be required.

\section{Introduction}

The relationship of phytoplankton photosynthesis to irradiance is fundamental not only to our understanding of marine productivity but also in predicting the response of marine systems to climate change and other anthropogenic alterations (Brown and Arrigo, 2012; Huot et al., 2013). This is especially true in high-latitude systems, where modifications in ice cover will bring dramatic changes in available irradiance and hence productivity (e.g., Montes-Hugo et al., 2008; Arrigo et al., 2013; Smith Jr. et al., 2014b), as well as changes in air-sea interactions and food-web dynamics (Smith Jr. et al., 2014a). Photosynthesis-irradiance $(P-E)$ relationships are also essential components of estimating productivity from satellite remote sensing data, as productivity is generally modeled as a function of integrated chlorophyll concentrations, available irradiance, and the $P-E$ response as a function of temperature (Behrenfeld and Falkowski, 1997; Platt et al., 2007). The temperature-photosynthesis relationship is generally assumed to be constant below $0{ }^{\circ} \mathrm{C}$ (Behrenfeld and Falkowski, 1997), despite the fact that substantial oceanographic variability is known in other variables that influence photosynthesis in these low-temperature seas.

$P-E$ responses are generally described by a relatively simple equation that parameterizes the response as a function of irradiance: $P_{\mathrm{s}}^{\mathrm{B}}$, the biomass-specific rate of photosynthesis at saturating irradiances in the absence of photoinhibition; $\alpha^{\mathrm{B}}$, the irradiance-limited, biomass-specific linear portion of the hyperbolic response; and $\beta^{\mathrm{B}}$, the portion of 
the curve where photosynthesis decreases at high irradiances (photoinhibition) (Platt et al., 1980a). $P_{\mathrm{m}}^{\mathrm{B}}$ is the biomassspecific, realized rate of photosynthesis at saturating irradiances. A parameter describing the irradiance at which saturation is initiated, $E_{k}$, is derived from the ratio of $P_{\mathrm{m}}^{\mathrm{B}}$ and $\alpha^{\mathrm{B}}$. Chlorophyll $a$ concentrations are generally used as an index of biomass. Estimates of photoinhibition are often difficult to obtain and are thought to represent a non-steady-state condition (Marra et al., 1985), and measurements often do not result in statistically significant estimates of $\beta^{\mathrm{B}}$ (van Hilst and Smith Jr., 2002; Huot et al., 2013); hence $\beta^{\mathrm{B}}$ is often assumed to be zero.

$P-E$ responses from the Southern Ocean have been assessed from a number of regions (e.g., West Antarctic Peninsula: Brightman and Smith Jr., 1989; Moline et al., 1998; Scotia Sea: Tilzer et al., 1986; Ross Sea: van Hilst and Smith Jr., 2002; Robinson et al., 2003; Smyth et al., 2012), but unlike for the Arctic Ocean (Platt et al., 1980b; Huot et al., 2013), no synthesis of photosynthetic responses or their environmental controls is available. Different investigators have also used slightly different methods, making a comparison more difficult; furthermore, because regions in the Southern Ocean change rapidly, it is challenging to interpret the results of changing $P-E$ responses in the context of spatial and temporal variability of oceanographic conditions. In general, phytoplankton in the Southern Ocean exhibit low maximum photosynthetic rates (between 1 and $\left.2 \mu \mathrm{g} \mathrm{C}(\mu \mathrm{g} \mathrm{Chl})^{-1} \mathrm{~h}^{-1}\right)$, and $E_{k}$ values reflect the in situ irradiance environment from which the phytoplankton were sampled. That is, when phytoplankton are sampled from within a deeply mixed surface layer or from under the ice, $E_{k}$ values are low, reflecting an acclimation to reduced available irradiance. Conversely, $E_{k}$ values generally increase when phytoplankton are sampled from stratified, ice-free environments in summer that are characterized by higher mean irradiance values.

The Ross Sea is among the best studied areas in the Antarctic, and a great deal is known about its oceanography, productivity, temporal and spatial variability, and food-web dynamics (Smith Jr. et al., 2012, 2014b). Despite a broad understanding of the system's characteristics, a full synthesis of the area's photosynthesis-irradiance relationships is lacking. It is known that the colonial haptophyte Phaeocystis antarctica typically blooms in austral spring and reaches high abundance (Tremblay and Smith Jr., 2007; Smith Jr. et al., 2014a), and disappears rapidly from the water column after reaching its seasonal maximum (Smith Jr. et al., 2011a). Laboratory and field investigations have shown that $P$. antarctica is well adapted to grow at low and variable irradiances characteristic of deeply mixed surface layers and under variable ice cover (Kroupenske et al., 2009; Arrigo et al., 2010). In contrast, diatoms often bloom after P. antarctica is reduced in biomass, but the magnitude of the diatom growth is highly variable among years (Peloquin and Smith Jr., 2007). Diatoms are in general capable of growth at higher photon flux densities, characteristic of stratified, summer conditions and close proximity to melting sea ice (Arrigo et al., 2010). The general distributions of both functional groups suggest that the photosynthetic capacity of each is different and reflects the in situ habitat that each is found. Despite this, van Hilst and Smith Jr. (2002) and Robinson et al. (2003) were unable to show a statistically significant difference between the $P-E$ responses of samples dominated by one functional group or the other. This suggests that the distribution of functional groups may be strongly influenced by factors other than just photosynthesis, despite photophysiological abilities and acclimations to different environments.

This study synthesizes the results from a large number of photosynthesis-irradiance measurements conducted at various times and locations in the Ross Sea. Given the generally predictable pattern of phytoplankton growth in the area (Phaeocystis antarctica blooms upon the removal of ice in relatively deep water columns, and drive the biomass maximum in late spring, and are followed by diatom growth; Smith Jr. et al., 2014b), we assessed the photosynthetic responses as a function of season. We also compared the various environmental controls (e.g., temperature, nitrate, and iron) on irradiance-saturated photosynthetic rates, as well as their relationship to assemblage composition.

\section{Methods}

\subsection{Analytical procedures}

Samples were collected during a number of cruises, most of which concentrated their sampling in the southern Ross Sea (Fig. 1). The first was IVARS (Interannual Variations in the Ross Sea; Smith Jr. et al., 2011a, b), which collected samples during short cruises twice each year, with the first cruise sampling ice-free periods in late December and the second sampling the end of summer (early February). The second project was CORSACS (Controls on Ross Sea Algal Community Structure), which had two cruises. The first cruise began in late December 2005 and the second was in NovemberDecember 2006 (Sedwick et al., 2011; Smith Jr. et al., 2013). $P-E$ results from CORSACS involved controlled, experimental manipulations of irradiance and dissolved iron and $\mathrm{CO}_{2}$ concentrations and used trace-metal clean procedures (Feng et al., 2010; Rose et al., 2010). The final project was PRISM (Processes Regulating Iron Supply at the Mesoscale), which sampled in January-February 2012 (Smith Jr. and Jones, 2014; McGillicuddy et al., 2015). Figure 1 shows the locations of the stations analyzed for photosynthesisirradiance relationships. Published measurements from other investigations are also included in the meta-analysis (e.g., van Hilst and Smith Jr., 2002; Robinson et al., 2003; Saggiomo et al., 2002; Hiscock, 2004; Smyth et al., 2012).

$P-E$ relationships of phytoplankton were determined by assessing uptake of ${ }^{14} \mathrm{C}$ bicarbonate in short incubations (Lewis and Smith, 1983). The largest difference among the 
Table 1. Listing of photosynthesis-irradiance responses used in this meta-analysis. $N$ : number of determinations; $V_{\text {inc }}$ : volume incubated; F/NF: filtered/not filtered.

\begin{tabular}{llrrll}
\hline Cruise name & Dates of sampling $(\mathrm{mm} / \mathrm{dd} /$ yyyy $)$ & $N$ & $V_{\text {inc }}(\mathrm{mL})$ & $\mathrm{F} / \mathrm{NF}$ & Reference \\
\hline RSP & $11 / 16 / 1994-11 / 30 / 1995 ;$ & 10 & 2 & $\mathrm{NF}$ & van Hilst and Smith Jr. (2002) \\
& $12 / 21 / 1995-1 / 13 / 1996$ & 54 & 2 & $\mathrm{NF}$ & \\
JGOFS & $11 / 16 / 1996-12 / 11 / 2006$ & 70 & 10 & $\mathrm{~F}$ & Hiscock (2004) \\
& $1 / 12 / 1997-2 / 8 / 2007$ & 87 & 10 & $\mathrm{~F}$ & \\
ROSSMIZ & $1 / 17 / 2007-4 / 26 / 2007$ & 5 & 10 & $\mathrm{~F}$ & \\
ROAVERRS & $11 / 1 / 1996-2 / 10 / 1996$ & 72 & 50 & $\mathrm{~F}$ & Saggiomo et al. (2002) \\
NBP05-08 & $11 / 8 / 2005-11 / 30 / 2005$ & 2 & $\mathrm{~F}^{*}$ & Robinson et al. (2003) \\
IVARS 1 & $12 / 19 / 2001-2 / 2 / 2002$ & 15 & 5 & $\mathrm{NF}$ & Smyth et al. (2012) \\
IVARS 3 & $12 / 26 / 2003-2 / 6 / 2004$ & 6 & 2 & $\mathrm{NF}$ & This report \\
IVARS 4 & $12 / 19 / 2004-1 / 31 / 2005$ & 9 & 2 & $\mathrm{NF}$ & This report \\
IVARS 5 & $12 / 26 / 2005-1 / 2 / 2006$ & 16 & 2 & $\mathrm{NF}$ & This report \\
CORSACS 1 & $12 / 27 / 2005-1 / 31 / 2006$ & 7 & 2 & $\mathrm{NF}$ & This report \\
CORSACS 2 & $11 / 16 / 2006-12 / 11 / 2006$ & 83 & 2 & $\mathrm{NF}$ & This report \\
PRISM & $1 / 8 / 2012-2 / 2 / 2012$ & 23 & 2 & $\mathrm{NF}$ & This report \\
\hline
\end{tabular}

* Gravity filtration

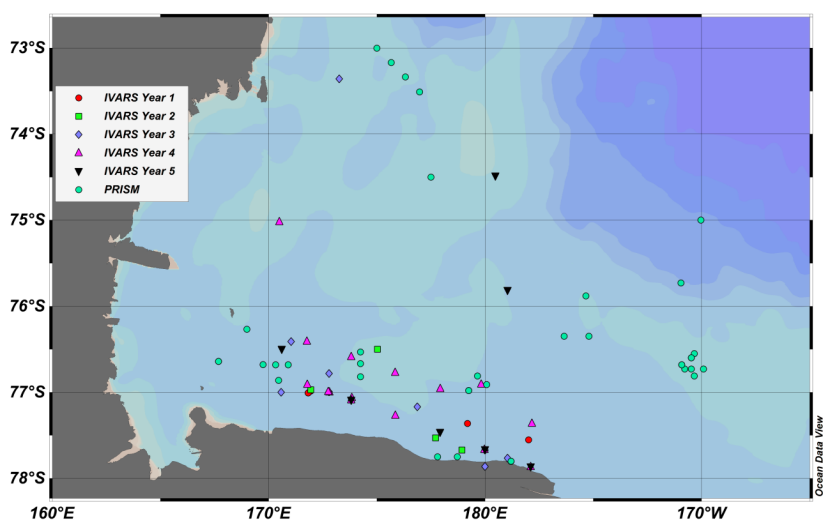

Figure 1. Map showing the location of the stations where photosynthesis-irradiance determinations were conducted.

different published reports was sample filtration; samples that were not filtered thus included any short-term DOC release (Table 1). Robinson et al. (2003) concluded that filtration of samples dominated by colonial Phaeocystis antarctica resulted in an underestimate of photosynthetic rates, but comparison within IVARS and CORSACS did not identify this systematic bias (Smith Jr., unpublished). Samples were generally collected from one or two depths (generally that of the 50 and $1 \%$ isolumes) at each station (50\% depths were generally from 1 to $4 \mathrm{~m}$, and $1 \%$ depths from 15 to $50 \mathrm{~m}$ ), to which ca. $100-150 \mu \mathrm{Ci}$ of $\mathrm{NaH}^{14} \mathrm{CO}_{3}$ was added. Incubations were conducted at a constant temperature from the depth of sampling (determined by the CTD cast and maintained by a circulating water bath). Samples were placed in glass scintillation vials in a photosynthetron that provided a wide range of irradiances, but ultraviolet radiation was ex- cluded by the incubation design. Photosynthetically available radiation was modified from the maximum value by neutral density screening at irradiances ca. $70 \%$ of the full irradiance, and by a combination of neutral and blue screening at lower irradiances (Laws et al., 1990). Darkened vials served as controls. Irradiance was measured for each sample; the total number of irradiances used ranged from 16 to 32. Incubations lasted approximately $2 \mathrm{~h}$. All samples were counted on liquid scintillation counters, and total available inorganic ${ }^{14} \mathrm{C}$ bicarbonate was assessed by counting aliquots of the original solution directly in scintillation fluor. While details of the methods of each study varied somewhat, we were unable to detect a significant difference between filtered and unfiltered results, and concluded that the methods did not introduce a significant source of error to obscure the overall patterns.

All data were fitted to the rectilinear hyperbolic model of Platt et al. (1980b):

$P^{\mathrm{B}}=P_{\mathrm{m}}^{\mathrm{B}}\left[1-\mathrm{e}^{-\alpha^{\mathrm{B}} E / P_{\mathrm{m}}^{\mathrm{B}}}\right]$,

where $P^{\mathrm{B}}$ is the rate of photosynthesis normalized to chlorophyll $a \quad\left[\mathrm{mgC} \quad(\mathrm{mgChl} a)^{-1} \mathrm{~h}^{-1}\right] ; \quad P_{\mathrm{m}}^{\mathrm{B}} \quad$ is the maximum realized irradiance-saturated rate of photosynthesis; $\alpha^{\mathrm{B}}$ is the initial, light-limited, linear photosynthetic rate normalized to chlorophyll $[\mathrm{mgC}$ $\left.(\mathrm{mgChl} a)^{-1} \mathrm{~h}^{-1}\left(\mu \mathrm{mol} \text { quanta } \mathrm{m}^{-2} \mathrm{~s}^{-1}\right)^{-1}\right]$; and $E$ is irradiance ( $\mu$ mol quanta $\mathrm{m}^{-2} \mathrm{~s}^{-1}$ ). All responses were fit to a two-parameter exponential increase to maxima in SigmaPlot 12.3, which provided estimates of $P_{\mathrm{m}}^{\mathrm{B}}$ and $\alpha^{\mathrm{B}}$ and their significance, as determined by a $t$ test. Some of the published analyses included $\beta^{\mathrm{B}}$, the photoinhibition parameter, but for consistency these were omitted in this meta-analysis, since $\beta^{\mathrm{B}}$ appears to represent a non-equilibrium condition and in our samples was not consistently evident (Denman 
and Marra, 1986; MacIntyre et al., 2002). Photoinhibitory data from stations where photoinhibition occurred were not removed, as the impact on photosynthetic parameters was generally minor. The derived parameter $E_{k}$ (the irradiance at which photosynthesis becomes saturated) is calculated by

$E_{k}=P_{\mathrm{m}}^{\mathrm{B}} / \alpha^{\mathrm{B}}$.

$E_{k}$ provides a measure by which the acclimation to irradiance can be compared. If the observations did not result in a significant determination of both $\alpha^{\mathrm{B}}$ and $P_{\mathrm{m}}^{\mathrm{B}}(p<0.05)$, then the entire sample was omitted from the meta-analysis.

Chlorophyll $a$ concentrations were analyzed by fluorometry (JGOFS, 1996) on independent samples collected from the same depth. Nutrient $\left(\mathrm{NO}_{3}, \mathrm{NO}_{2}, \mathrm{PO}_{4}, \mathrm{Si}(\mathrm{OH})_{4}, \mathrm{NH}_{4}\right)$ analyses were performed at sea on a Lachat QuickChem autoanalyzer using standard automated techniques, or on frozen samples after return to the laboratory. Mixed-layer depths were determined from density profiles determined from CTD casts using a change in density of $0.01 \mathrm{~kg} \mathrm{~m}^{-3}$ from a stable surface value (Thomson and Fine, 2003; Smith Jr. et al., 2013). Seawater samples for dissolved iron analysis were collected in custom-modified $5 \mathrm{~L}$ Teflon-lined, external-closure Niskin-X samplers (General Oceanics Inc.) or $10 \mathrm{~L}$ Teflon-lined GO-FLO samplers, all of which were deployed on a non-metal line (Sedwick et al., 2011). Filtered samples were acidified to $\mathrm{pH} 1.7$ with ultrapure hydrochloric acid and stored for at least $24 \mathrm{~h}$ prior to the analysis of dissolved iron. Dissolved iron was determined by flow injection analysis with colorimetric detection after in-line pre-concentration on resin-immobilized 8-hydroxyquinoline (Sedwick et al., 2008).

\subsection{Statistical analyses}

Comparisons between data sets were made using analyses of variance. An a priori limit of significance was set as $p<0.05$. Data were tested for normality and homogeneity of variance, and ANOVAs were performed using $R$ (v2.13.2). Stations selected for a comparison of the effects of assemblage composition were chosen based on HPLC analysis of pigments and the contribution of each functional group to total chlorophyll (Mackey et al., 1996). When pigment data were not included in the published reports, taxonomic discrimination was made by reported microscopic results.

\section{Results}

\subsection{IVARS, CORSACS, and PRISM photosynthesis-irradiance determinations}

$P-E$ determinations in IVARS were conducted during the peak of the spring bloom (generally late December) and at the end of summer (early February) (Smith Jr. et al., 2011a). Ice concentrations were $<15 \%$ at all stations.
Table 2. Mean and standard deviations of photosynthesisirradiance parameters, mixed-layer depths $\left(Z_{\mathrm{mix}}\right)$, and euphotic zone depths $\left(Z_{1 \%}\right)$ determined during IVARS and PRISM cruises. Units: $\alpha^{\mathrm{B}}: \mu \mathrm{gC}(\mu \mathrm{gChl})^{-1} \mathrm{~h}^{-1}\left(\mu \mathrm{mol} \text { quanta } \mathrm{m}^{-2} \mathrm{~s}^{-1}\right)^{-1} ; P_{\mathrm{m}}^{\mathrm{B}}$ : $\mu \mathrm{g} \mathrm{C}(\mu \mathrm{g} \mathrm{Chl})^{-1} \mathrm{~h}^{-1} ; E_{k}: \mu \mathrm{mol}$ quanta $\mathrm{m}^{-2} \mathrm{~s}^{-1} ; Z_{\mathrm{mix}}: \mathrm{m} ; Z_{1 \%}: \mathrm{m}$. Number of observations in parentheses.

\begin{tabular}{llrrrrr}
\hline Month & Year & $\alpha^{\mathrm{B}}$ & $P_{\mathrm{m}}^{\mathrm{B}}$ & $E_{k}$ & $Z_{\mathrm{mix}}$ & $Z_{1 \%}$ \\
\hline December & 2001 & $0.060 \pm$ & $2.3 \pm$ & $42 \pm$ & $37 \pm 13$ & $9.38 \pm$ \\
& & $0.015(4)$ & 0.61 & 18 & $(17)$ & $1.06(8)$ \\
February & 2002 & $0.008(1)$ & 0.85 & 110 & $35 \pm 9$ & $14.3 \pm$ \\
& & & & & $(16)$ & $2.74(9)$ \\
December & 2002 & $0.033 \pm$ & $0.97 \pm$ & $34 \pm$ & $29 \pm 7$ & $36.0 \pm$ \\
& & $0.012(4)$ & 0.32 & 24 & $(8)$ & $14.5(3)$ \\
December & 2003 & $0.019 \pm$ & $0.61 \pm$ & $37 \pm$ & $23 \pm 10$ & $27.8 \pm$ \\
& & $0.005(5)$ & 0.36 & 28 & $(12)$ & $11.4(9)$ \\
February & 2004 & $0.067 \pm$ & $0.80 \pm$ & $16 \pm$ & $25 \pm 9$ & $25.8 \pm$ \\
& & $0.047(4)$ & 0.57 & 15 & $(25)$ & $6.57(12)$ \\
December & 2004 & $0.022 \pm$ & $1.1 \pm$ & $62 \pm$ & $21 \pm 6$ & $23.8 \pm$ \\
& & $0.009(10)$ & 0.42 & 38 & $(23)$ & $7.66(23)$ \\
February & 2005 & $0.051 \pm$ & $0.57 \pm$ & $14 \pm$ & $20 \pm 7$ & $24.6 \pm$ \\
& & $0.023(6)$ & 0.048 & 6.1 & $(24)$ & $8.20(25)$ \\
December & 2005 & $0.070 \pm$ & $1.6 \pm$ & $28 \pm$ & $20 \pm 11$ & $24.0 \pm$ \\
& & $0.055(7)$ & 0.80 & 11 & $(12)$ & $1.91(7)$ \\
Mean: & - & $0.040 \pm$ & $1.3 \pm$ & $42 \pm$ & $26 \pm 12$ & $23.0 \pm$ \\
December & & $0.035(27)$ & 0.72 & 29 & $(72)$ & $10.1(50)$ \\
Mean: & - & $0.053 \pm$ & $0.68 \pm$ & $23 \pm$ & $26 \pm 10$ & $22.9 \pm$ \\
February & & $0.035(11)$ & 0.34 & 30 & $(65)$ & $8.13(45)$ \\
PRISM, & 2010 & $0.035 \pm$ & $1.1 \pm$ & $52 \pm$ & $28 \pm 23$ & $42.2 \pm 22.8$ \\
January & & $0.020(77)$ & 0.50 & 48 & $(116)$ & $(116)$ \\
\hline
\end{tabular}

Average $\alpha^{\mathrm{B}}, P_{\mathrm{m}}^{\mathrm{B}}$, and $E_{k}$ values for the IVARS spring and summer cruises were $0.040 \pm 0.035$ and $0.053 \pm 0.035 \mu \mathrm{g} \mathrm{C}$ $(\mu \mathrm{g} \mathrm{Chl})^{-1} \mathrm{~h}^{-1} \quad\left(\mu \mathrm{mol} \text { quanta } \mathrm{m}^{-2} \mathrm{~s}^{-1}\right)^{-1}, \quad 1.3 \pm 0.72$ and $0.68 \pm 0.34 \mu \mathrm{gC}(\mu \mathrm{g} \mathrm{Chl})^{-1} \mathrm{~h}^{-1}$, and $42 \pm 29$ and $23 \pm 30 \mu$ mol quanta $\mathrm{m}^{-2} \mathrm{~s}^{-1}$, respectively (Table 2). $P_{\mathrm{m}}^{\mathrm{B}}$ values of the two seasons were significantly different $(p<0.05)$, but $\alpha^{\mathrm{B}}$ and $E_{k}$ values were not.

CORSACS measurements were largely conducted as part of experiments that manipulated irradiance (7 and $33 \%$ of surface irradiance), iron concentrations (ambient and $+1 \mathrm{nM}$ ), and $\mathrm{CO}_{2}$ concentrations (380 and $\left.750 \mu \mathrm{atm}\right)$ (Feng et al., 2010). Natural populations were used as inocula in semi-continuous cultures grown at constant irradiances (Hutchins et al., 2003), and $P-E$ determinations were made through time on all treatments to assess the impact of each variable (and their interactions) on short-term photosynthetic responses. Irradiance variations resulted in significantly $(p<0.05)$ decreased $P_{\mathrm{m}}^{\mathrm{B}}$ and increased $\alpha^{\mathrm{B}}$ values at the low and constant irradiances used (Fig. 2). No net changes were noted in $E_{k}$ means. Increased $\mathrm{CO}_{2}$ concentrations also resulted in significantly $(p<0.05)$ increased $\alpha^{\mathrm{B}}$ and $P_{\mathrm{m}}^{\mathrm{B}}$ values, although again little net change was noted in $E_{k}$ values. Finally, increased iron concentrations in these experiments did not impact either $\alpha^{\mathrm{B}}$ or $P_{\mathrm{m}}^{\mathrm{B}}$ values significantly (Fig. 2). However, iron concentrations at the end of the 18-day experiment ranged from 0.09 to $0.98 \mathrm{nM}$ and were largely above concentrations that are considered to be limiting (Timmermans et al., 2004). Therefore, any effect of iron 

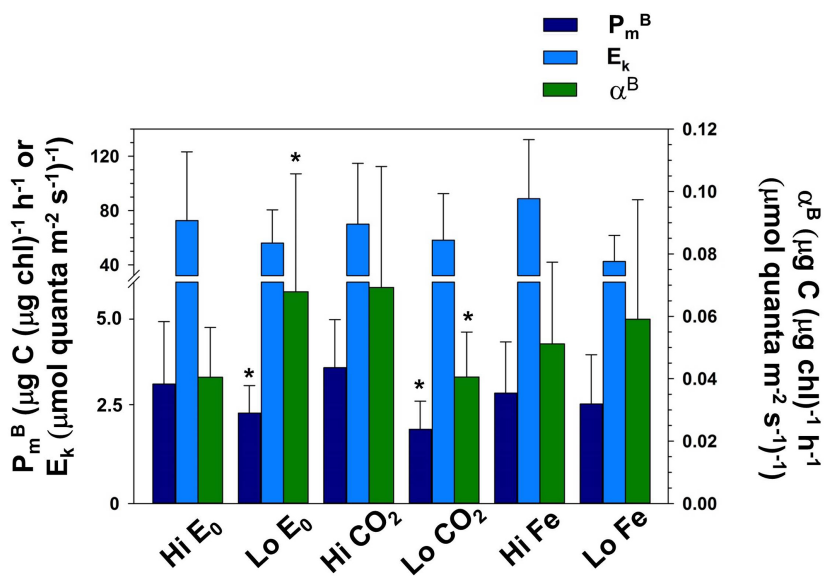

Figure 2. Photosynthesis-irradiance parameters determined from experimental manipulations of natural populations. Samples had high or low (33 or $7 \%$ of surface value) irradiance, high or low (750 or $380 \mathrm{ppm}) \mathrm{CO}_{2}$, and high or low $(+1 \mathrm{nM}$ and ambient; ca. $0.1 \mathrm{~nm}$ ) iron concentrations. Asterisks indicate a significant difference between the high and low treatments within each variable $(*: p<0.05)$

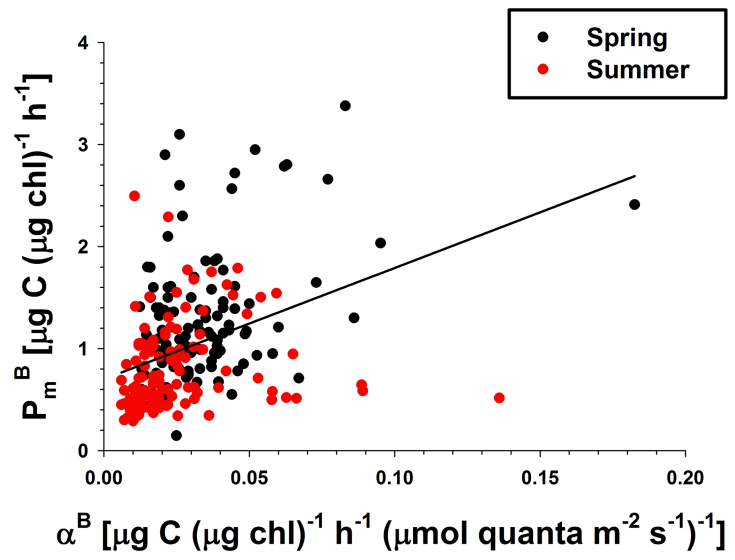

Figure 3. Relationship of $\alpha^{\mathrm{B}}$ (light-limited photosynthesis) and $P_{\mathrm{m}}^{\mathrm{B}}$ (irradiance-saturated photosynthesis) in samples from the Ross Sea. Solid line is the linear regression $\left(P_{\mathrm{m}}^{\mathrm{B}}=10.9 \alpha^{\mathrm{B}}+0.70 ; r^{2}=0.15\right.$; $p<0.001)$.

on photosynthetic parameters was not well tested in this experiment. Observed mean $P_{\mathrm{m}}^{\mathrm{B}}$ values were greater than those representing suboptimal, in situ conditions such as in IVARS and PRISM.

PRISM samples investigated the broad spatial patterns of $P-E$ responses (Table 2). The mean $\alpha^{\mathrm{B}}$ and $P_{\mathrm{m}}^{\mathrm{B}}$ values were $0.035 \pm 0.020\left(\mu \mathrm{gC} \quad(\mu \mathrm{g} \mathrm{Chl})^{-1} \mathrm{~h}^{-1}\right.$ $\left.\left(\mu \mathrm{mol} \text { quanta } \mathrm{m}^{-2} \mathrm{~s}^{-1}\right)^{-1}\right)$ and $1.1 \pm 0.50 \mu \mathrm{gC}(\mu \mathrm{g} \mathrm{Chl})^{-1}$ $\mathrm{h}^{-1}$, respectively. The average $E_{k}$ value was $52 \pm 48 \mu$ mol quanta $\mathrm{m}^{-2} \mathrm{~s}^{-1}$. There was no significant difference between PRISM $P-E$ parameters and those collected during IVARS (December, February, or the total data set), and again no spatial pattern was observed.

Temperature, iron, and nitrate concentrations were measured during PRISM at a number of stations where $P-E$ measurements were conducted (McGillicuddy et al., 2015). The data were arbitrarily divided above and below $20 \mu \mathrm{M}$ $\mathrm{NO}_{3}$ and above and below $0{ }^{\circ} \mathrm{C}$, and the $P-E$ parameters were compared. Dissolved Fe concentrations ranged from 0.066 to $0.69 \mathrm{nM}$, and nitrate ranged from 9.1 to $30.6 \mu \mathrm{M}$. Sample temperatures ranged from -1.6 to $2.6^{\circ} \mathrm{C}$; 58 of the $102 P-E$ determinations were below $0^{\circ} \mathrm{C}$, and 44 were above. No significant difference in the mean $\alpha^{\mathrm{B}}, P_{\mathrm{m}}^{\mathrm{B}}$, or $E_{k}$ values were observed between the stations with nitrate concentrations less than $20 \mu \mathrm{M}$ and those with concentrations $>20 \mu \mathrm{M}$ (Table 3), which is not unexpected as these concentrations are considered to be far above levels thought to be limiting. In contrast, at stations with $\mathrm{Fe}$ concentrations below and above $0.10 \mathrm{nM}$ (a level that approximates the onset of Fe limitation in Antarctic phytoplankton; Timmermans et al., 2004), $P_{\mathrm{m}}^{\mathrm{B}}$ values were significantly $(p<0.01)$ greater $(1.6 \pm 0.55$ vs. $0.95 \pm 0.44)$ at lower iron concentrations (Table 3$). \alpha^{\mathrm{B}}$ and $E_{k}$ values, however, were not significantly different, suggesting that iron largely impacts irradiancesaturated photosynthetic rates, which in turn are largely controlled by carbon fixation processes. No significant differences were noted for any of the three photosynthetic parameters within the temperature data subset, corroborating the PRISM results (Table 3). This result suggests that photosynthetic responses are largely independent of temperature over short timescales.

There was no significant relationship in the combined IVARS, JGOFS, and PRISM data between any photosynthetic parameter from samples collected at 50 vs. $1 \%$ of surface irradiance. This lack of correlation differs from the CORSACS results (Fig. 2), which were conducted under constant irradiance using natural assemblages (but which changed appreciably during the experiments). Available irradiances at the time of sampling do not necessarily reflect the irradiance that influenced growth over times scales of days to weeks, which are unknown and likely highly variable. This indicates that there is no substantial photoacclimation within water columns of the Ross Sea, which in turn may suggest that the time needed for acclimation at these temperatures is longer than the timescales of water column perturbation.

\subsection{Comparison with previous $\boldsymbol{P}-\boldsymbol{E}$ determinations}

Because $P-E$ determinations have been conducted during the past two decades with a similar methodologies, we merged all data from the Ross Sea to assess the average photosynthetic response by season (Table 4). There is a significant difference between austral spring and summer averages for $P_{\mathrm{m}}^{\mathrm{B}}$ and $\alpha^{\mathrm{B}}$ values, with spring having greater $P_{\mathrm{m}}^{\mathrm{B}}(1.4$ vs. 0.86$)$ and $\alpha^{\mathrm{B}}$ values (0.034 vs. 0.023$)$. However, no significant difference was observed between spring and 
Table 3. Comparison of PRISM photosynthetic parameters as a function of nitrate, temperature, and iron (means and standard deviations). Range of data listed in parentheses. The available data were divided into those stations that had nitrate concentrations above and below $20 \mu \mathrm{M}$, in situ temperatures above and below $0{ }^{\circ} \mathrm{C}$, and iron concentrations greater than or less than $0.1 \mathrm{nM}$. No significant differences were noted between the two sets of parameters except where noted.

\begin{tabular}{|c|c|c|c|c|}
\hline Variable group & $N$ & $\begin{array}{r}\alpha^{\mathrm{B}} \\
\left(\mu \mathrm{g} \mathrm{C}(\mu \mathrm{g} \mathrm{Chl})^{-1} \mathrm{~h}^{-1}\right. \\
\left.\left(\mu \mathrm{mol} \text { quanta } \mathrm{m}^{-2} \mathrm{~s}^{-1}\right)^{-1}\right)\end{array}$ & $\left(\mu \mathrm{gC}(\mu \mathrm{g})^{-1} \mathrm{~h}^{-1} p_{\mathrm{m}}^{\mathrm{B}}\right.$ & $\left(\mu \mathrm{mol}\right.$ quanta $\left.\mathrm{m}^{-2} \mathrm{~s}^{-1}\right)$ \\
\hline$\left[\mathrm{NO}_{3}\right]<20 \mu \mathrm{M}$ & 58 & $\begin{array}{l}0.035 \pm 0.020 \\
(0.012-0.095)\end{array}$ & $\begin{array}{l}1.2 \pm 0.64 \\
(0.29-3.1)\end{array}$ & $\begin{array}{l}43 \pm 34 \\
(7-193)\end{array}$ \\
\hline$\left[\mathrm{NO}_{3}\right]>20 \mu \mathrm{M}$ & 56 & $\begin{array}{l}0.043 \pm 0.039 \\
(0.008-0.183)\end{array}$ & $\begin{array}{l}1.2 \pm 0.58 \\
(0.21-2.8)\end{array}$ & $\begin{array}{l}48 \pm 47 \\
(4-238)\end{array}$ \\
\hline$T>0^{\circ} \mathrm{C}$ & 44 & $\begin{array}{l}0.040 \pm 0.036 \\
(0.015-0.183)\end{array}$ & $\begin{array}{l}1.2 \pm 0.66 \\
(0.29-3.1)\end{array}$ & $\begin{array}{l}44 \pm 40 \\
(7-193)\end{array}$ \\
\hline$T<0^{\circ} \mathrm{C}$ & 58 & $\begin{array}{l}0.032 \pm 0.021 \\
(0.011-0.095)\end{array}$ & $\begin{array}{l}1.2 \pm 0.53 \\
(0.21-2.7)\end{array}$ & $\begin{array}{l}50 \pm 44 \\
(8-238)\end{array}$ \\
\hline$[\mathrm{Fe}]<0.1 \mathrm{nM}$ & 6 & $\begin{array}{r}0.038 \pm 0.023 \\
(0.021-0.053)\end{array}$ & $\begin{array}{r}1.6 \pm 0.55^{*} \\
(1.1-2.7)\end{array}$ & $\begin{array}{l}41 \pm 18 \\
(28-54)\end{array}$ \\
\hline$[\mathrm{Fe}]>0.1 \mathrm{nM}$ & 33 & $\begin{array}{l}0.029 \pm 0.017 \\
(0.011-0.066)\end{array}$ & $\begin{array}{r}0.95 \pm 0.44 \\
(0.21-1.7)\end{array}$ & $\begin{array}{l}48 \pm 36 \\
(8-131)\end{array}$ \\
\hline
\end{tabular}

$* t$ test indicated a significant difference $(p<0.01)$.

Table 4. Seasonal comparison of photosynthetic parameters from the Ross Sea.

\begin{tabular}{|c|c|c|c|c|c|}
\hline $\begin{array}{l}\text { Season } \\
\left(\mu \mathrm{g} \mathrm{C}(\mu \mathrm{g} \mathrm{Chl})^{-1} \mathrm{~h}^{-1}\right)\end{array}$ & $\left(\mu \mathrm{gC}(\mu \mathrm{gChl})^{-1} \mathrm{~h}^{-1} P_{\mathrm{m}}^{\mathrm{B}}\right.$ & $\begin{array}{r}\alpha^{\mathrm{B}} \\
\left(\mu \mathrm{mol} \text { quanta } \mathrm{m}^{-2} \mathrm{~s}^{-1}\right) \\
\left.\left(\mu \mathrm{mol} \text { quanta } \mathrm{m}^{-2} \mathrm{~s}^{-1}\right)^{-1}\right)\end{array}$ & $E_{k}$ & $N$ & Reference \\
\hline Spring & $1.7 \pm 0.97$ & $0.047 \pm 0.023$ & $37 \pm 7.5$ & 37 & van Hilst and Smith Jr. (2002) \\
\hline Summer & & $0.087 \pm 0.043$ & $31 \pm 16$ & 31 & \\
\hline Spring & $1.2 \pm 0.54$ & $0.036 \pm 0.015$ & $37 \pm 13$ & 70 & Hiscock (2004) \\
\hline Summer & $0.64 \pm 0.26$ & $0.016 \pm 0.007$ & $44 \pm 18$ & 98 & \\
\hline Autumn & $0.70 \pm 0.13$ & $0.040 \pm 0.017$ & $21 \pm 9$ & 5 & \\
\hline Summer & $1.3 \pm 0.39$ & $0.073 \pm 0.088$ & $23 \pm 8$ & 51 & Saggiomo et al. (2002) \\
\hline Spring & $1.8 \pm 0.68$ & $0.020 \pm 0.004$ & $89 \pm 23$ & 15 & Robinson et al. (2003) \\
\hline Spring ${ }^{2}$ & $2.1 \pm 0.48$ & $0.072 \pm 0.027$ & $31 \pm 8.0$ & 10 & Smyth et al. (2012) \\
\hline Spring & $1.3 \pm 0.72$ & $0.040 \pm 0.035$ & $42 \pm 29$ & 27 & IVARS: this report \\
\hline Summer & $0.68 \pm 0.34$ & $0.053 \pm 0.035$ & $23 \pm 30$ & 11 & IVARS: this report \\
\hline Summer & $1.1 \pm 0.500$ & $0.035 \pm 0.020$ & $52 \pm 48$ & 77 & PRISM: this report \\
\hline Mean spring $^{1}$ & $1.4 \pm 0.63$ & $0.034 \pm 0.024$ & $44 \pm 25$ & 159 & - \\
\hline Mean summer ${ }^{1}$ & $0.86 \pm 0.45$ & $0.023 \pm 0.018$ & $43 \pm 28$ & 268 & - \\
\hline Mean $^{1}$ & $1.1 \pm 0.60$ & $0.030 \pm 0.023$ & $44 \pm 27$ & 417 & - \\
\hline
\end{tabular}

${ }^{1}$ Weighted mean of all samples. ${ }^{2} \alpha^{\mathrm{B}}$ and $E_{k}$ values calculated from data using factor described in original paper.

summer $E_{k}$ values. Values of $\alpha^{\mathrm{B}}$ and $P_{\mathrm{m}}^{\mathrm{B}}$ were linearly correlated $\left(P_{\mathrm{m}}^{\mathrm{B}}=10.9 \alpha^{\mathrm{B}}+0.070 ; \quad R^{2}=0.15 ; \quad p<0.001\right.$; Fig. 3), as has been found previously (Harrison and Platt, 1980; van Hilst and Smith Jr., 2002; Behrenfeld et al., 2004), but the large amount of variability in the relationship suggests that each is being influenced by multiple independent factors as well. No interannual temporal trend was obvious, and interannual variability was substantial (Table 4$)$. The overall $P_{\mathrm{m}}^{\mathrm{B}}$ average for all samples $(N=417)$ equaled $1.1 \pm 0.60 \mu \mathrm{g} \mathrm{C} \quad(\mu \mathrm{g} \mathrm{Chl})^{-1} \mathrm{~h}^{-1}, \quad \alpha^{\mathrm{B}}=0.030 \pm 0.023 \mu \mathrm{g} \mathrm{C}$ $(\mu \mathrm{g} \mathrm{Chl})^{-1} \mathrm{~h}^{-1} \quad\left(\mu \mathrm{mol} \text { quanta } \mathrm{m}^{-2} \mathrm{~s}^{-1}\right)^{-1}, \quad$ and $\quad E_{k}=$ $44 \pm 27 \mu$ mol quanta $\mathrm{m}^{-2} \mathrm{~s}^{-1}$.

\subsection{Controls by environmental factors and phytoplankton composition}

We tested for the effects of nitrate and temperature from the depth of sampling on $P-E$ parameters from all cruises. The data were arbitrarily divided above and below $20 \mu \mathrm{M}$ $\mathrm{NO}_{3}$ and above and below $0{ }^{\circ} \mathrm{C}$, and the $P-E$ parameters 
were compared. Nitrate concentrations at the time of sampling ranged from 9.1 to $30.6 \mu \mathrm{M}$, and $56 P-E$ measurements were conducted with $\mathrm{NO}_{3}$ concentrations greater than $20 \mu \mathrm{M}$. Fifty-eight analyses were conducted with $\mathrm{NO}_{3}$ levels less than $20 \mu \mathrm{M}$. Sample temperatures ranged from -1.6 to $2.6^{\circ} \mathrm{C}$; 58 of the $102 P-E$ determinations were below $0{ }^{\circ} \mathrm{C}$, and 44 were above. No significant differences were noted for any of the three photosynthetic parameters within the nitrate or temperature data subsets, corroborating the PRISM results (Table 3). This suggests that photosynthetic responses are largely independent of these environmental controls over short timescales.

The two dominant functional groups in the Ross Sea, diatoms and haptophytes (largely Phaeocystis antarctica), have different temporal and spatial distributions, with $P$. antarctica generally dominating in spring in water columns with deeper vertical mixing, and diatoms dominating in more stratified, summer conditions (Smith Jr. et al., 2014a). $P$. antarctica largely occurs in cold waters $\left(<0{ }^{\circ} \mathrm{C}\right)$ and is responsible for the spring reduction in micro- and macronutrients (Liu and Smith Jr., 2012). To investigate whether the two taxa have different photosynthesis-irradiance responses, we selected 20 stations for each group that were identified by chemical or microscopic means as being dominated by one of these groups, and assessed their $P-E$ characteristics (Table 5). We found no statistical difference between the two groups with respect to $\alpha^{\mathrm{B}}, P_{\mathrm{m}}^{\mathrm{B}}$, or $E_{k}$ values.

\section{Discussion}

\subsection{Overall patterns of photosynthetic parameters}

One major finding of this meta-analysis is that the average maximum, light-saturated rate of photosynthesis equals $1.1 \mu \mathrm{g} \mathrm{C}(\mu \mathrm{g} \mathrm{Chl})^{-1} \mathrm{~h}^{-1}$ (Table 4). This is similar to the $P_{\mathrm{opt}}^{\mathrm{B}}$ value determined from Behrenfeld and Falkowski (1997) polynomial equation $\left(1.3 \mu \mathrm{g} \mathrm{C}(\mu \mathrm{g} \mathrm{Chl})^{-1} \mathrm{~h}^{-1}\right)$ at $0{ }^{\circ} \mathrm{C}$, despite the difference between $P_{\mathrm{opt}}^{\mathrm{B}}$ and $P_{\mathrm{m}}^{\mathrm{B}}$ as well as the range of temperatures at which the $P-E$ determinations were conducted. Our results reinforce the validity of using their equation to estimate maximum photosynthetic rates and primary productivity within the waters of the Ross Sea, and presumably the entire Southern Ocean. This average can also be used in other bio-optical models of production to constrain the rates of carbon fixation over broad areas (e.g., Arrigo et al., 2003, 2008). However, given the seasonal variability observed, more detailed models that incorporate seasonal and environmental impacts on photosynthetic parameters may require inclusion of other oceanographic variables (especially iron concentrations) to more accurately predict production.

We found relatively minor spatial differences in photosynthetic parameters but significant seasonal differences. Specifically, $\alpha^{\mathrm{B}}$ and $P_{\mathrm{m}}^{\mathrm{B}}$ values of the entire meta-analysis data set were significantly greater during spring than summer (both $p<0.001$ ), which is consistent with the large seasonal changes found in nearly all oceanographic and biological variables. The macro-environment of the Ross Sea continental shelf changes markedly from spring to summer, with increased temperatures, stronger vertical stratification, shallower mixed layers, decreased macro- and micronutrient concentrations, and an altered assemblage composition (Smith Jr. et al., 2012). All of these variables have been shown to influence $P-E$ responses in laboratory and field studies (e.g., MacIntyre et al., 2002; Xie et al., 2015), and as such, it is not surprising that the $P-E$ parameters also changed. It is tempting to suggest that the seasonal changes were driven by changes in phytoplankton composition, but we believe that the seasonal changes in oceanographic conditions led to in changes in $P-E$ parameters as well as in composition, and that both oceanographic changes and phytoplankton composition contributed to the seasonal differences in $P-E$ parameters we observed. An experiment which isolates natural assemblages (perhaps a Lagrangian tracking of a parcel of water that is dominated by one taxa or a large-volume mesocosm experiment such as has been conducted in the Baltic Sea; Riebesell et al., 2013) would be more definitive test of the impacts of composition and the seasonal changes in $P-E$ parameters. Clearly the growth environment usually found in summer in the Ross Sea is not favorable to high photosynthetic rates, a conclusion that have been consistently corroborated by direct measurements of productivity (e.g., Long et al., 2011). It was impossible to accurately assess interannual variations in $P-E$ parameters, given the relatively low numbers of samples in some years, but in view of the large variations observed in biomass and productivity from 1995 through 2010 (Smith Jr. and Comiso, 2008; Smith Jr. et al., 2011a), any interannual trend is likely obscured by the substantial seasonal variability.

\subsection{Controls of photosynthesis-irradiance parameters}

While not all data sets had complete macro- and micronutrient data available for inclusion, we were unable to detect any controls of short-term photosynthetic rates by temperature or nitrate within the seasonal data sets. The temperature range was modest (ca. $4{ }^{\circ} \mathrm{C}$ ), so the direct impact of temperature may have been limited and obscured by other factors. Liu and Smith Jr. (2012) demonstrated that the environmental factor that had the strongest impact on phytoplankton biomass and composition was temperature. They found that diatoms were more likely to be found in waters above $0^{\circ} \mathrm{C}$, and in subzero waters assemblage composition was more often dominated by Phaeocystis antarctica. Waters with temperatures less than $0^{\circ} \mathrm{C}$ also tend to have deeper mixed layers, reducing mean irradiance available for growth, which also favors the growth of $P$. antarctica (Tremblay and Smith Jr., 2007). Nitrate concentrations varied more widely (from 9.3 to $31 \mu \mathrm{M}$ ), but still remained above those thought to limit nitrogen uptake (Cochlan et al., 2002). Xie et al. (2015) also did not find 
Table 5. Comparison of the mean photosynthesis-irradiance parameters as a function of phytoplankton composition (means and standard deviations). Dominance was determined by either chemical or microscopic analyses. Twenty stations for each functional group $(N)$ from the entire data set were selected for inclusion in this comparison. No significant difference in any photosynthetic parameter was detected.

\begin{tabular}{|c|c|c|c|}
\hline Functional group & $P_{\mathrm{m}}^{\mathrm{B}}\left(\mu \mathrm{g} \mathrm{C}(\mu \mathrm{g} \mathrm{Chl})^{-1} \mathrm{~h}^{-1}\right)$ & $\begin{array}{l}\alpha^{\mathrm{B}}\left(\mu \mathrm{g} \mathrm{C}(\mu \mathrm{g} \mathrm{Chl})^{-1} \mathrm{~h}^{-1}\right) \\
\left.\left(\mu \mathrm{mol} \text { quanta m}{ }^{-2} \mathrm{~s}^{-1}\right)^{-1}\right)\end{array}$ & $E_{k}\left(\mu \mathrm{mol}\right.$ quanta $\left.\mathrm{m}^{-2} \mathrm{~s}^{-1}\right)$ \\
\hline $\begin{array}{l}\text { Phaeocystis } \\
\text { antarctica }(N=20)\end{array}$ & $1.4 \pm 0.76$ & $0.067 \pm 0.060$ & $33 \pm 23$ \\
\hline Diatoms $(N=20)$ & $1.1 \pm 0.63$ & $0.050 \pm 0.045$ & $32 \pm 19$ \\
\hline
\end{tabular}

a correlation between nutrients and $P_{\mathrm{m}}^{\mathrm{B}}$, and suggested that this reflected the lag time between nutrient inputs and phytoplankton growth in the English Channel. They also found a complicated relationship between photosynthetic parameters and temperature and suggested that each functional group had temperature optima that were characterized by specific photosynthetic responses.

Reduced in situ iron concentrations in PRISM, however, resulted in elevated $P_{\mathrm{m}}^{\mathrm{B}}$ values, despite the relatively limited number of measurements at concentrations less than $0.1 \mathrm{nM}$ (Table 3). In contrast, we did not detect a change at the end of the controlled experiments (CORSACS) in which iron concentrations were measured. However, all but one of those conditions had dissolved Fe concentrations $>0.13 \mathrm{nM}$ (Feng et al., 2010) at the end of the 18-day experiment, concentrations which are greater than those generally found in situ (Sedwick et al., 2011). Furthermore, given that the lowest $\mathrm{Fe}$ concentration at the experiment's termination was $0.09 \mathrm{nM}$, it would be expected that preceding levels were even greater and may have obscured any Fe effect. Because the experiments were completed in a constant irradiance environment, the impact of iron also may have been lessened. Iron influences growth rates of Antarctic diatoms (Timmermans et al., 2004), but growth rate responses are integrated over many days, whereas $P-E$ responses are not immediately influenced by iron additions (Hiscock et al., 2008). It is tempting to suggest that the reduced summer $P-E$ parameters may have resulted from iron limitation, but iron availability is rarely determined in parallel with $P-E$ parameters. We suggest that the impacts of iron we observed - significantly increased $P_{\mathrm{m}}^{\mathrm{B}}$ values under low Fe concentrations - were mediated by a long-term assemblage response rather than an impact on short-term photosynthetic rates. Iron limitation can impact chlorophyll synthesis (in a manner similar to irradiance), and under iron and irradiance co-limitation, chlorophyll levels can be elevated (Sunda and Huntsman, 1997), which would result in altered $P_{\mathrm{m}}^{\mathrm{B}}$ values. Determination of the exact cause of the iron effect on $P_{\mathrm{m}}^{\mathrm{B}}$, however, is impossible with the present data set.

The CORSACS experiments showed a clear impact of both irradiance and $\left[\mathrm{CO}_{2}\right]$ on photosynthetic responses. Under low and constant irradiance conditions (ca. $7 \%$ that of surface irradiance), there was an increase in the light-limited rates of photosynthesis $\left(\alpha^{\mathrm{B}}\right)$ and light-saturated $\left(P_{\mathrm{m}}^{\mathrm{B}}\right)$ values (Fig. 2). Low-irradiance conditions often generate increased chlorophyll concentrations per cell, but can also generate increased photosynthetic efficiencies (via changes in photosynthetic units), which can result in elevation of both parameters (Prezelin, 1981; Dubinsky and Stambler, 2009). $P_{\mathrm{m}}^{\mathrm{B}}$ reflects the light-saturated rate, and presumably is set by the amount of carbon that can be reduced by the cells, which in turn is thought to be limited by the amount of chemical energy generated by the cells' photosystems. Increasing carbon dioxide concentrations resulted in a marked and significant increase in $P_{\mathrm{m}}^{\mathrm{B}}$ and $\alpha^{\mathrm{B}}$ values, reinforcing the classical view of the limitation of short-term photosynthesis by carbon availability under high-irradiance conditions. Enhanced $\alpha^{\mathrm{B}}$ values may reflect the interaction between light-limited and light-saturated rates described by Behrenfeld et al. (2004), in which the two covary and result in the maintenance of a relatively constant $E_{k}$. Interestingly, increased $\mathrm{CO}_{2}$ levels had little impact on phytoplankton composition (Tortell et al., 2008b), and independent measurements suggest that most Antarctic phytoplankton have a relatively broad capability to use a wide range of carbon dioxide concentrations (Tortell et al., 2008a). Although it is tempting to suggest that future increases in oceanic $\mathrm{CO}_{2}$ concentrations might increase maximum photosynthetic rates, such changes need to be assessed using long-term experiments that allow for acclimation and adaptation over many generations (e.g., Lohbeck et al., 2012).

The influence of phytoplankton composition was insignificant (Table 5). This is consistent with the previous results of van Hilst and Smith Jr. (2002) and Robinson et al. (2003) using less extensive data sets, but in contrast to the extensive laboratory results of Arrigo et al. (2010), who found that $\alpha^{\mathrm{B}}$ and $P_{\mathrm{m}}^{\mathrm{B}}$ values of $P$. antarctica grown at constant irradiances (from 5 to $125 \mu \mathrm{mol}$ quanta $\mathrm{m}^{-2} \mathrm{~s}^{-1}$ ) and saturating nutrients were always greater than those of the diatom Fragilariopsis cylindrus. The diatom had low $P_{\mathrm{m}}^{\mathrm{B}}$ (from 0.46 to $\left.0.54 \mu \mathrm{gC}(\mu \mathrm{g} \mathrm{Chl})^{-1} \mathrm{~h}^{-1}\right)$ and $\alpha^{\mathrm{B}}$ values $(0.014$ to 0.043 $\left.\left(\mu \mathrm{g} \mathrm{C}(\mu \mathrm{g} \mathrm{Chl})^{-1} \mathrm{~h}^{-1}\left(\mu \mathrm{mol} \text { quanta } \mathrm{m}^{-2} \mathrm{~s}^{-1}\right)^{-1}\right)\right)$ when compared to those of the haptophyte (from 1.4 to 6.4 , and 0.038 to 0.11 , respectively). The diatom parameters determined in culture were lower than in our data subset, and the haptophyte values higher; these differences likely reflect the pa- 
rameters of the individual species cultured and/or the acclimation to constant culturing conditions. The in situ data also had substantial variability, which likely resulted at least in part from the environmental conditions that allowed one particular functional group to dominate. In addition to the influence of environmental conditions, individual species likely have evolved mechanisms to permit adaptation within a wide environmental range. Appearance of taxa in situ reflects a long-term process involving both growth and losses, and both field and laboratory data suggest that the $P-E$ parameters of the dominant forms in spring and summer reflect the importance of selected environmental features (irradiance, iron) on their long-term success within the water column.

In summary, the broad photosynthetic responses of Ross Sea phytoplankton are consistent with the patterns used in global production estimates from satellite biomass estimates. However, strong and significant seasonal differences occur, as do variations driven by irradiance, iron concentrations, and carbon dioxide levels. Such significant differences may need to be included in regional models of productivity and carbon flux. While these results may suggest that future changes in photosynthetic capacity and production in the Ross Sea as a result of climate change could be substantial, confirmation of this will require future analyses of these parameters.

Acknowledgements. This research was supported through National Science Foundation grant ANT-0944254 to W. O. Smith Jr. P. Sedwick generously allowed the use of his iron data from the PRISM cruise. We thank all our colleagues for their assistance at sea, especially L. Delizo and V. Asper. This is VIMS contribution number 3467.

Edited by: C. Robinson

\section{References}

Arrigo, K. R., Worthen, D. L., and Robinson, D. H.: A coupled ocean-ecosystem model of the Ross Sea: 2. Iron regulation of phytoplankton taxonomic variability and primary production, J. Geophys. Res., 108, doi:10.1029/2001JC000856, 2003.

Arrigo, K. R., van Dijken, G. L., and Bushinsky, S.: Primary production in the Southern Ocean, 1997-2006, J. Geophys. Res., 113, C08004, doi:10.1029/2007JC004551, 2008.

Arrigo, K. R., Mills, M. M., Kropuenske, L. R., van Dijken, G. L., Alderkamp, A.-C., and Robinson, D. H.: Photophysiology in two major Southern Ocean phytoplankton taxa: photosynthesis and growth of Phaeocystis antarctica and Fragilariopsis cylindrus under different irradiance levels, Integr. Comp. Biol., 50, 950966, 2010

Arrigo, K. R., Perovich, D. K., Pickart, R. S., Brown, Z. W., van Dijken, G. L., Lowry, K. E., Mills, M. M., Palmer, M. A., Balch, W. M., Bahr, F., Bates, N. R., Benitez-Nelson, C., Bowler, B., Brownlee, E., Ehn, J. K., Frey, K. E., Garley, R., Laney, S. R., Lubelczyk, L., Mathis, J., Matsuoka, A., Mitchell, B. G., Moore, G. W. K., Ortega-Retuerta, E., Pal, S., Polashenski, C.
M., Reynolds, R. A., Scheiber, B., Sosik, H. M., Stephens, M., and Swift, J. H.: Massive phytoplankton blooms under Arctic sea ice, Science, 336, 1408, 2013.

Behrenfeld, M. J. and Falkowski, P. G.: Photosynthetic rates derived from satellite-based chlorophyll concentrations, Limnol. Oceanogr., 42, 1-20, 1997.

Behrenfeld, M. J., Prasil, O., Babin, M., and Bruyant, F.: In search of a physiological basis for covariations in light-limited and light-saturated photosynthesis, J. Phycol., 40, 4-25, 2004.

Brightman, R. I. and Smith Jr., W. O.: Photosynthesis-irradiance relationships of Antarctic phytoplankton during austral winter, Mar. Ecol.-Prog. Ser., 53, 143-151, 1989.

Brown, W. and Arrigo, K. R.: Contrasting trends in sea ice and primary production in the Bering Sea and Arctic Ocean, ICES J. Mar. Sci., 69, 1180-1193, doi:10.1093/icesjms/fss113, 2012.

Cochlan, W. P., Bronk, D. A., and Coale, K. H.: Trace metals and nitrogenous nutrition of Antarctic phytoplankton: experimental observations in the Ross Sea, Deep-Sea Res. Pt. II, 49, 33653390, 2002.

Denman, K. L. and Marra, J.: Modelling the time dependent photoadaptation of phytoplankton to fluctuating light, in: Marine Interfaces Ecohydrodynamics, edited by: Nioul, J. C., Elsevier Oceanography Series, Amsterdam, 42, 341-359, 1986.

Dubinsky, Z. and Stambler, N.: Photoacclimation processes in phytoplankton: mechanisms, consequences, and applications, Aquat Microb. Ecol., 56, 163-176, 2009.

Feng, Y., Hare, C. E., Rose, J. M., Handy, S. M., DiTullio, G. R., Lee, P., Smith Jr., W. O., Peloquin, J., Tozzi, S., Sun, J., Zhang, Y., Dunbar, R. B., Long, M. C., Sohst, B., and Hutchins, D.: Interactive effects of $\mathrm{CO}_{2}$, irradiance and iron on Ross Sea phytoplankton, Deep-Sea Res. Pt. I, 57, 368-383, doi:10.1016/j.dsr.2009.10.013, 2010.

Harrison, W. G. and Platt, T.: Variations in assimilation number of coastal marine phytoplankton: effects of environmental covariates, J. Plankton Res., 2, 249-260, 1980.

Hiscock, M. R.: The regulation of primary productivity in the Southern Ocean, PhD Diss., Duke Univiversity, Durham, 120 pp., 2004.

Hiscock, M. R., Lance, V. P., Apprill, A. M., Johnson, Z., Bidigare, R. R., Mitchell, B. G., Smith Jr., W. O., and Barber, R. T.: Photosynthetic maximum quantum yield increases are an essential component of Southern Ocean phytoplankton iron response, $\mathrm{P}$. Natl. Acad. Sci. USA, 105, 4775-4780, 2008.

Huot, Y., Babin, M., and Bruyant, F.: Photosynthetic parameters in the Beaufort Sea in relation to the phytoplankton community structure, Biogeosciences, 10, 3445-3454, doi:10.5194/bg10-3445-2013, 2013.

Hutchins, D. A., Hare, C. E., Pustizzi, F. P., Trick, C. G., and DiTullio, G. R.: A shipboard natural community continuous culture system to examine effects of low-level nutrient enrichments on phytoplankton community composition, Limnol. Oceanogr.Meth., 1, 82-91, 2003.

JGOFS: Protocols for the Joint Global Ocean Flux Study (JGOFS) core measurements, IOC SCOR Rpt. 19, Bergen, Norway, 1996.

Kropuenske, L. R., Mills, M. M., Van Dijken, G. L., Bailey, S., Robinson, D. H., Welschmeyer, N. A., and Arrigo, K. R.: Photophysiology in two major Southern Ocean phytoplankton taxa: photoprotection in Phaeocystis antarctica and Fragilariopsis cylindrus, Limnol. Oceanogr.-Meth., 54, 1176-1196, 2009. 
Laws, E. A., DiTullio, G. R., Carder, K. L., Betzer, P. R., and Hawes, S.: Primary production in the deep blue sea, Deep-Sea Res., 37 , 715-730, 1990.

Lewis, M. R. and Smith, J. C.: A small volume, short-incubationtime method for measurement of photosynthesis as a function of incident irradiance, Mar. Ecol.-Prog. Ser., 13, 99-102, 1983.

Liu, X. and Smith Jr., W. O.: A statistical analysis of the controls on phytoplankton distribution in the Ross Sea, Antarctica, J. Marine Syst., 94, 135-144, 2012.

Lohbeck, K. T., Riebesell, U., and Reutsch, T. B. H.: Adaptive evolution of a key phytoplankton species to ocean acidification, Nat. Geosci., 5, 346-351, 2012.

Long, M. C., Dunbar, R. B., Tortell, P. D., Smith Jr., W. O., Mucciarone, D. A., and DiTullio, G. R.: Vertical structure, seasonal drawdown, and net community production in the Ross Sea, Antarctica, J. Geophys. Res., 116, C10029, doi:10.1029/2009JC005954, 2011.

MacIntyre, H. L, Kana, T. M., Anning, T., and Geider, R. J.: Photoacclimation of photosynthesis irradiance response curves and photosynthetic pigments in microalgae and cyanobacteria, J. Phycol., 38, 17-38, 2002.

Mackey, M. D., Mackey, D. J., Higgins, H. W., and Wright, S. W.: CHEMTAX - a program for estimating class abundances from chemical markers: application to HPLC measurements of phytoplankton, Mar. Ecol.-Prog. Ser., 144, 265-283, 1996.

Marra, J., Heinemann, K., and Landriau Jr., G.: Observed and predicted measurements of photosynthesis in a phytoplankton culture exposed to natural irradiance, Mar. Ecol.-Prog. Ser., 24, 43$50,1985$.

McGillicuddy Jr., D. M., Sedwick, P. N., Dinniman, M. S., Arrigo, K. R., Bibby, T. S., Greenan, B. J. W., Hofmann, E. E., Klinck, J. M., Smith Jr., W. O., Mack, S. L., Marsay, C. M., Sohst, B. M., and van Dijken, G.: Iron supply and demand in an Antarctic shelf system, Geophys. Res. Lett., in press, 2015.

Moline, M. A., Schofield, O., and Boucher, N. P.: Photosynthetic parameters and empirical modelling of primary production: a case study on the Antarctic Peninsula shelf, Antarct. Sci., 10, 45-54, 1998.

Montes-Hugo, M., Doney, S. C., Ducklow, H. W., Fraser, W., Martinson, D., Stammerjohn, S. E., and Schofield, O.: Recent changes in phytoplankton communities associated with rapid regional climate change along the Western Antarctic Peninsula, Science, 323, 1470-1473, 2008.

Peloquin, J. A. and Smith Jr., W. O.: Phytoplankton blooms in the Ross Sea, Antarctica: Interannual variability in magnitude, temporal patterns, and composition, J. Geophys. Res., 112, C08013, doi:10.1029/2006JC003816, 2007.

Platt, T., Gallegos, C. L., and Harrison, W. G.: Photoinhibition of photosynthesis in natural assemblages of marine phytoplankton, J. Mar. Res., 38, 687-701, 1980a.

Platt, T., Harrison, W. G., Irwin, B., Horne, E. P., and Gallegos, C. L.: Photosynthesis and photoadaptation of marine phytoplankton in the arctic, Deep-Sea Res., 29, 1159-1170, 1980b.

Platt, T., Sathyendranath, S., and Fuentes-Yaco, C.: Biological oceanography and fisheries management: perspective after 10 years, ICES J. Mar. Sci., 5, 863-869, 2007.

Prezelin, B. B.: Light Reactions in Photosynthesis, in: Physiological Bases of Phytoplankton Ecology, edited by: Platt, T., Can. B. Fish. Aquat. Sci., 210, 1-43, 1981.
Riebesell, U., Czerny, J., von Bröckel, K., Boxhammer, T., Büdenbender, J., Deckelnick, M., Fischer, M., Hoffmann, D., Krug, S. A., Lentz, U., Ludwig, A., Muche, R., and Schulz, K. G.: Technical Note: A mobile sea-going mesocosm system - new opportunities for ocean change research, Biogeosciences, 10, 18351847, doi:10.5194/bg-10-1835-2013, 2013.

Robinson, D. H., Arrigo, K. R., DiTullio, G. R., and Lizotte, M. P.: Evaluating photosynthetic carbon fixation during Phaeocystis antarctica blooms, in: Biogeochemistry of the Ross Sea, edited by: DiTullio, G. R. and Dunbar, R. B., Ant. Res. Ser., American Geophysical Union, Washington, DC, 78, 77-92, 2003.

Rose, J. M., Feng, Y., DiTullio, G. R., Dunbar, R. B., Hare, C. E., Lee, P. A., Lohan, M., Long, M., W. O. Smith Jr., Sohst, B., Tozzi, S., Zhang, Y., and Hutchins, D. A.: Synergistic effects of iron and temperature on Antarctic phytoplankton and microzooplankton assemblages, Biogeosciences, 6, 3131-3147, doi:10.5194/bg-6-3131-2009, 2009.

Saggiomo, V., Catalano, G., Mangoni, O., Budillon, G., and Carrada, G. C.: Primary production processes in ice-free waters of the Ross Sea (Antarctica) during the austral summer 1996, DeepSea Res. Pt. II, 49, 1787-1801, 2002.

Sedwick, P. N., Bowie, A. R., and Trull, T. W.: Dissolved iron in the Australian sector of the Southern Ocean (CLIVAR-SR3 section): meridional and seasonal trends, Deep-Sea Res. Pt. I, 55, 911925, 2008.

Sedwick, P. N., Marsay, C. M., Aguilar-Islas, A. M., Lohan, M. C., Sohst, B. M., Long, M. C., Arrigo, K. R., Dunbar, R. B., Saito, M. A., Smith, W. O., and DiTullio, G. R.: Early-season depletion of dissolved iron in the Ross Sea polynya: Implications for iron dynamics on the Antarctic continental shelf, J. Geophys. Res., 116, C12019, doi:10.1029/2010JC006553, 2011.

Smith Jr., W. O. and Comiso, J. C.: The influence of sea ice on primary production in the Southern Ocean: a satellite perspective, J. Geophys. Res., 113, C05S93, doi:10.1029/2007JC004251, 2008

Smith Jr., W. O. and Jones, R. M.: Vertical mixing, critical depths, and phytoplankton growth in the Ross Sea, ICES J. Mar. Sci., doi:10.1093/icesjms/fsu234, 2014.

Smith Jr., W. O., Asper, V., Tozzi, S., Liu, X., and Stammerjohn, S. E.: Surface layer variability in the Ross Sea, Antarctica as assessed by in situ fluorescence measurements, Prog. Oceanogr., 88, 28-45, 2011a.

Smith Jr., W. O., Shields, A. R., Dreyer, J., Peloquin, J. A., and Asper, V.: Interannual variability in vertical export in the Ross Sea: magnitude, composition, and environmental correlates, DeepSea Res. Pt. I, 58, 147-159, 2011 b.

Smith Jr., W. O., Sedwick, P. N., Arrigo, K. R., Ainley, D. G., and Orsi, A. H.: The Ross Sea in a sea of change, Oceanography, 25, 44-57, 2012.

Smith Jr., W. O., Tozzi, S., Sedwick, P. W., DiTullio, G. R., Peloquin, J. A., Long, M,. Dunbar, R., Hutchins, D. A., and Kolber, Z.: Spatial and temporal variations in variable fluorescence in the Ross Sea (Antarctica): environmental and biological correlates, Deep-Sea Res. Pt. I, 79, 141-155, 2013.

Smith Jr., W. O., Ainley, D. G., Arrigo, K. R., and Dinniman, M. S.: The oceanography and ecology of the Ross Sea, Annu. Rev. Mater. Sci., 6, 469-487, 2014a.

Smith Jr., W. O., Dinniman, M. S., Hoffman, E. E., and Klinck, J.: Modeled impacts of changing winds and temperatures on the 
oceanography of the Ross Sea in the 21st century, Geophys. Res. Lett., 41, 1624-1631, doi:10.1002/2014GL059311, 2014b.

Smyth, R. L., Sobrino, C., Phillips-Kress, J., Kim, H.-C., and Neele, P. J.: Phytoplankton photosynthetic response to solar ultraviolet irradiance in the Ross Sea polynya: development and evaluation of time-dependent model with limited repair, Limnol. Oceanogr., 57, 1602-1618, 2012.

Sunda, W. G. and Huntsman, S. A.: Interrelated influence of iron, light and cell size on marine phytoplankton growth, Nature, 390, 389-392, 1997.

Thompson, R. E. and Fine, I. V.: Estimating mixed layer depth from oceanic profile data, J. Atmos. Ocean. Tech., 20, 319-329, 2003.

Tilzer, M. M., Elbrachter, M., Gieskes, W. W., and Beese, B.: Light-temperature interaction in the control of photosynthesis in Antarctic phytoplankton, Polar Biol., 5, 105-111, 1986.

Timmermans, K. R., Gerringa, L. J. A., de Baar, H. J. W., van der Wagt, B., Veldhuis, M. J. W., de Jong, J. T. M., Croot, P. L., and Boye, M.: Growth rates of large and small Southern Ocean diatoms in relation to availability of iron in natural seawater, Limnol. Oceanogr., 46, 260-266, 2004.
Tortell, P. D., Payne, C., Gueguen, C., Strzepek, R. F., Boyd, P. W., and Rost, B.: Inorganic carbon uptake by Southern Ocean phytoplankton, Limnol. Oceanogr., 53, 1266-1278, 2008a.

Tortell, P. D., Payne, C., Li, Y., Trimborne, S., Rost, B., Smith Jr., W. O., Riesselman, C., Dunbar, R. B., Sedwick, P., and DiTullio, G. R.: $\mathrm{CO}_{2}$ sensitivity of Southern Ocean phytoplankton, Geophys. Res. Lett., 35, L04605, doi:10.1029/2007GL032583, 2008 b.

Tremblay, J.-E. and Smith Jr., W. O.: Phytoplankton processes in polynyas, in: Polynyas: Windows to the World's Oceans, edited by: Smith Jr., W. O. and Barber, D. G., Elsevier, Amsterdam, 239-270, 2007.

van Hilst, C. M. and Smith Jr., W. O.: Photosynthesis/irradiance relationships in the Ross Sea, Antarctica, and their control by phytoplankton assemblage composition and environmental factors, Mar. Ecol.-Prog. Ser., 226, 1-12, 2002.

Xie, Y., Tilstone, G. H., Widdicombe, C., Woodward, E. M. S., Harris, C., and Barnes, M. K.: Effect of increases in temperature and nutrients on phytoplankton community structure and photosynthesis in the western English Channel, Mar. Ecol.-Prog. Ser., 519, 61-73, 2015. 